\title{
14,500 years of vegetation and land use history in the upper continental montane zone at Lac de Champex (Valais, Switzerland)
}

\author{
Fabian Rey ${ }^{1,2,3}$ - Sandra O. Brugger ${ }^{2,3,4}$ (C) Erika Gobet $^{2,3}$ (1) $\cdot$ Romain Andenmatten $^{5} \cdot$ Andrea Bonini $^{2}$. \\ Hannah Inniger ${ }^{2} \cdot$ Corina Maurer $^{2} \cdot$ Nina Perret-Gentil-dit-Maillard $^{2} \cdot$ Julian C. Riederer $^{2} \cdot$ Oliver Heiri $^{1}$ (1) . \\ Willy Tinner ${ }^{2,3} \cdot$ Christoph Schwörer ${ }^{2,3}$ (1)
}

Received: 8 July 2021 / Accepted: 2 September 2021 / Published online: 9 November 2021

(c) The Author(s) 2021

\begin{abstract}
Forests in the upper continental montane zone are important ecotones between lowland and subalpine forest ecosystems. A thorough understanding of the past vegetation dynamics at mid elevation is crucial to assess past and future altitudinal range shifts of tree species in response to climate change. Lake sediments from Lac de Champex (1,467 m a.s.l.), a small lake in the Canton Valais in the Central Swiss Alps were analysed to reconstruct the vegetation, land use and fire history for the last 14,500 years, using pollen, macrofossils, non-pollen palynomorphs and charcoal. The record indicates that the tree line had already reached the Champex area during the Allerød (14,000 cal вр) but dropped below the lake's catchment during the Younger Dryas cooling (12,750-11,550 cal вр). Reforestation started again with Betula and Pinus sylvestris in the Early Holocene at 11,500 cal BP in response to rapid climate warming. Temperate tree species (Ulmus, Tilia, Quercus, Acer) may have reached the altitude of the lake during the Holocene Thermal Maximum (ca. 10,000-5,000 cal вр). Mixed forests with mesophilous Abies alba were dominant between 7,500 and 5,000 cal BP. The mass expansions of Picea abies after 5,000 cal вр and Alnus viridis thickets after 4,500 cal вР were directly linked to increasing human disturbance. High values of coprophilous Sporormiella fungal spores and cereal pollen suggest pastoral and arable farming at the site from the Late Neolithic/Early Bronze Age onwards (5,000 cal вP). Our data imply that vegetation at intermediate elevation was less affected by human activities than at higher or lower elevations but that these areas served as important stations between the permanent settlements in the valleys and the seasonally occupied alpine huts at higher elevations. We argue that future climate warming will lead to drastic reorganizations of mountain ecosystems.
\end{abstract}

Keywords Afforestation $\cdot$ Alpine farming $\cdot$ Central Alps $\cdot$ Human impact $\cdot$ Palaeoecology $\cdot$ Tree line

\section{Introduction}

Communicated by F. Bittmann.

Fabian Rey

fabian.rey@unibas.ch

1 Department of Environmental Sciences, University of Basel, Klingelbergstrasse 27, 4056 Basel, Switzerland

2 Institute of Plant Sciences, University of Bern, Altenbergrain 21, 3013 Bern, Switzerland

3 Oeschger Centre for Climate Change Research, University of Bern, Hochschulstrasse 4, 3012 Bern, Switzerland

4 Division of Hydrologic Sciences, Desert Research Institute, 2215 Raggio Parkway, Reno, NV 89512, USA

5 Cantonal Office of Archaeology, Canton of Valais, Route de la Piscine 10, 1950 Sion, Switzerland
Mountain ecosystems are considered to be particularly prone to environmental changes since distances for vertical migration are short and ecological gradients are generally steep (IPCC 2014). The projected temperature increase by the end of the 21 st century will likely lead to drastic shifts in the vegetation ranges and might result in a loss of biodiversity (CH2011 2011; IPCC 2014; Trisos et al. 2020). Specifically, temperate tree species (such as Ulmus, Tilia, Acer) may invade the boreal forests at mid altitudes (Thöle et al. 2016) and an upward movement of the tree line is very likely, replacing species-rich alpine meadows (Gehrig-Fasel et al. 2007; Harsch et al. 2009). However, to predict future changes in mountain ecosystems, it is essential to understand species responses to climate and human impacts over long 
(decadal to millennial scale) time periods. Here, palaeoecological approaches (e.g. sedimentary pollen and plant macrofossil analyses) are best suited to study long-term changes in terrestrial ecosystems and to constrain responses of key tree species to climatic and land use change.

Reconstructions of past vegetation dynamics have a long tradition in the Alps (e.g. Welten 1950a, b, 1944, 1952, 1982a; Zoller 1960; Burga 1980). Yet, only a limited number cover the mid altitudes (Welten 1982a, b; Rey et al. 2013) and some of the older studies do not have a reliable radiocarbon chronology (Welten 1982a, b), which is crucial for site-to-site comparisons at centennial time scales (Rey et al. 2019b). The consideration of plant macrofossil assemblages is particularly important for tree line reconstructions to unambiguously confirm the local presence of tree species (Birks 2001). Unfortunately, only a few well-dated, multiproxy reconstructions in the Alps are available (Gobet et al. 2003; Tinner and Theurillat 2003; Wick et al. 2003; Genries et al. 2009; Blarquez et al. 2010; Berthel et al. 2012; Rey et al. 2013; Schwörer et al. 2014; Thöle et al. 2016; Finsinger et al. 2021) and modern studies from the upper continental montane zone in the Central Alps (ca. 1,300-1,850 m a.s.l., Landolt et al. 2015) are currently lacking.

Mountain regions have been affected by land use for millennia (e.g. Gobet el al. 2003; Wick et al. 2003; Lotter et al. 2006; Rey et al. 2013). On the one hand, the impacts of human activities at the tree line in the upper subalpine zone are well-documented (Finsinger and Tinner 2007; Schwörer et al. 2014; Dietre et al. 2020) and it is known that many high elevation sites were used for pastoral farming since at least the Neolithic (ca. 7,500 cal BP, Schwörer et al. 2015). On the other hand, human activities and their impacts at mid altitudinal locations between the permanent settlements in the valleys and the seasonally occupied mayens and alpages (montane, subalpine and alpine huts) or camps at higher elevations remain ambiguous. Only few settlements above $1,000 \mathrm{~m}$ a.s.l. are documented for the Late Iron Age and beyond (>2,050 cal вP, David-Elbiali 1994; Curdy 2007), even though crop cultivation in the upper continental montane zone would have been possible and is documented until the recent past (Landolt et al. 2015). However, an in-depth assessment of the land use history (arable vs. pastoral farming) at mid altitudes is missing so far.

In the current study, we present the results of a new, welldated multiproxy reconstruction from Lac de Champex, Valais, Switzerland (1,467 $\mathrm{m}$ a.s.1.), covering the last 14,500 years. The lake is located in the upper continental montane zone and is well-suited for reconstructing the vegetation and land use history at mid altitudes. Our novel site may help to determine changes in tree line elevation since the Last Glacial Maximum (LGM) with the help of pollen and plant macrofossil analyses. Special attention is paid to tree line fluctuations between the Bølling (ca. 14,500 cal BP) and the onset of the Holocene (ca.
$11,500 \mathrm{cal}$ вP) as well as to the early human impact from ca. $7,000 \mathrm{cal}$ BP onward. The aims of this study are to (1) improve our understanding of changes in tree line position in response to climatic changes before the Holocene and (2) to assess the farming history of the upper continental montane zone.

\section{Study site}

Lac de Champex is a small mountain lake in the Pennine Alps ca. $15 \mathrm{~km}$ south of Martigny (Valais, Switzerland; Fig. 1). The lake $\left(46^{\circ} 1^{\prime} 39.025^{\prime \prime} \mathrm{N}, 7^{\circ} 07^{\prime} 07.9433^{\prime \prime} \mathrm{E}\right)$ is situated at $1,467 \mathrm{~m}$ a.s.l. on siliceous bedrock (Schmid et al. 2004). The lake surface area is $0.11 \mathrm{~km}^{2}$ and the maximum water depth is $5.2 \mathrm{~m}$. There are two small open inlets in the West and one covered outlet in the East. One of the inlets is an artificial water channel (French 'bisse') probably built in the Middle Ages, bringing fresh water from the neighbouring Arpette Valley (Lugon 1927).

The mean annual temperature is ca. $5.6{ }^{\circ} \mathrm{C}$ based on the closest weather station in Montana at similar altitude (1,427 m a.s.l.) ca. $40 \mathrm{~km}$ from Lac de Champex (MeteoSwiss 2021). The highest average temperatures are reached in July with ca. $14.4{ }^{\circ} \mathrm{C}$ and the lowest mean temperatures are measured in January with ca. $-2.1^{\circ} \mathrm{C}$. The annual precipitation is $786 \mathrm{~mm}$ down in the valley in Orsières $(929 \mathrm{~m}$ a.s.1.) ca. $2 \mathrm{~km}$ from the lake (MeteoSwiss 2021). The precipitation is evenly distributed throughout the year.

The lake is located in the upper continental montane zone (Landolt et al. 2015). Typical for this ecotone is the transition from pine-dominated (continental montane zone) to spruce-dominated forests (subalpine zone). Most of the surrounding area is covered by more or less closed forests dominated by coniferous tree species (Picea abies, Pinus sylvestris and Larix decidua) and few deciduous Betula pendula. The present tree line is at ca. 2,400 m a.s.l. on the slopes of the Catogne mountain north of the lake. Peatlands exist in the western part of the lake, close to the inlets. The modern village Champex-Lac is situated along the northern and eastern lake shores and developed from a mayen with local fields ('champ' = field in French). There is a high density of archaeological sites in the region covering the Mesolithic to Modern times (Fig. 1). Most of the sites are located along the main valleys (Val d'Entremont, Val de Bagnes, Rhône Valley). Those valleys were important pathways for crossing the Alps via mountain passes such as Col du Gd-St-Bernard.

\section{Materials and methods}

\section{Coring and chronology}

In October 2015, two parallel sediment cores (CHX-A and CHX-B) were taken in the eastern part of the lake at a water 


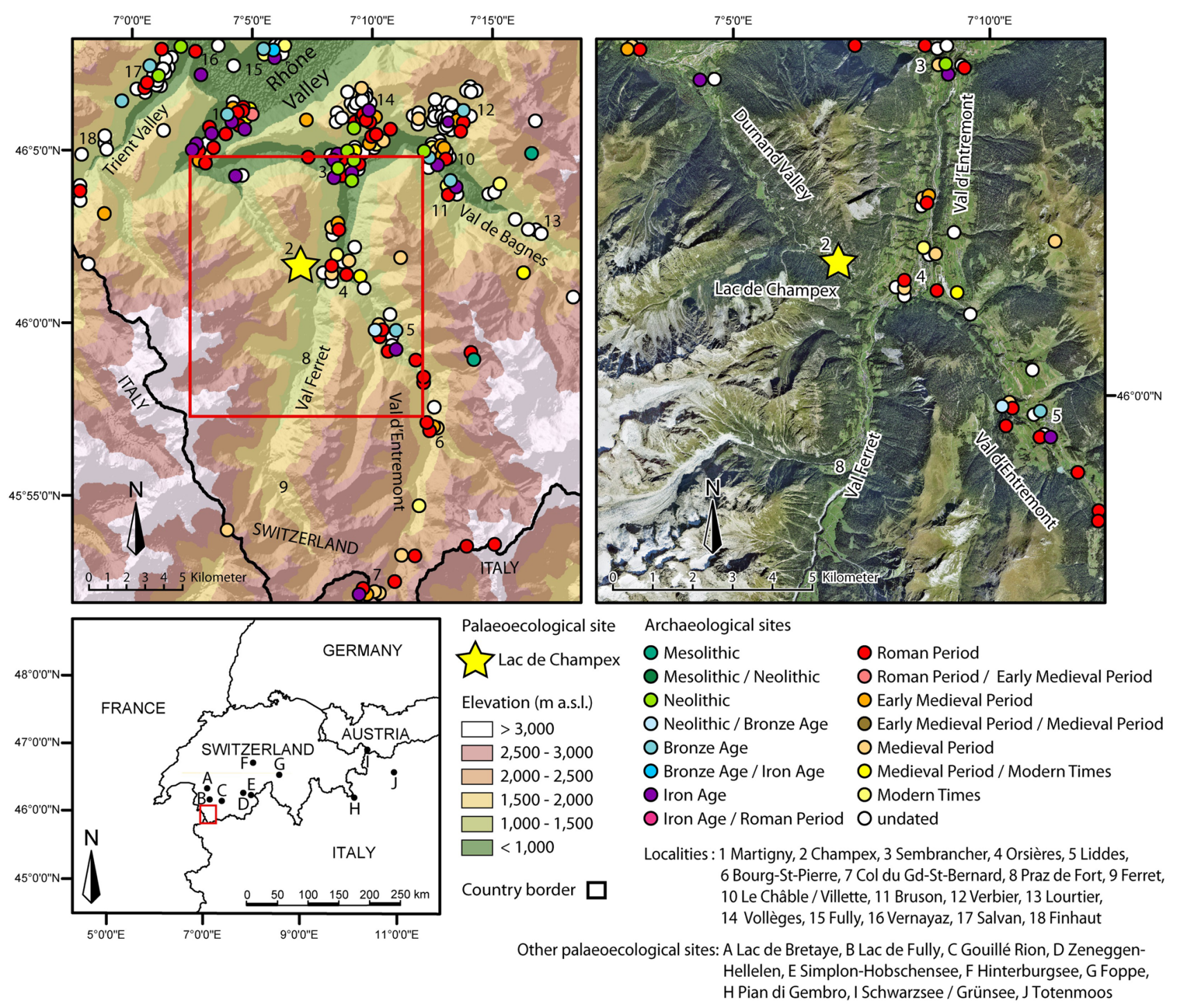

Fig. 1 Overview map of Lac de Champex (1,467 m a.s.l., yellow star) and the study region (Canton of Valais, Switzerland) including a selection of other discussed palaeoecological sites (black circles,

depth of $5.2 \mathrm{~m}$ using an UWITEC-piston corer (core diameter: $66 \mathrm{~mm}$, coring chamber: $3 \mathrm{~m}$ ). A total coring depth of $6.5 \mathrm{~m}$ was reached. One additional surface core (CHX-S1) was retrieved to recover the surface sediments. Core segments were cut into $1 \mathrm{~m}$ intervals in the field and then integrated to one master sequence of $612.5 \mathrm{~cm}$ in the laboratory based on visually identified, lithological marker layers.

The age-depth model is based on 13 radiocarbon dates from terrestrial plant macrofossils, the Laacher See Tephra (LST) and one pollen stratigraphical marker (Table 1). The radiocarbon contents of the plant macrofossils were measured at the LARA laboratory at the University of Bern (Szidat et al. 2014). Two additional radiocarbon dates were rejected prior to the age-depth modelling. The program letters), archaeological sites (Mesolithic to Modern Times, coloured circles) and other localities (settlements/mountain pass, numbers). Source of the maps: NASADEM 2020, swisstopo

CALIB 8.2 was used to calibrate the radiocarbon dates using the IntCal20 calibration curve (Reimer et al. 2020). The age-depth model was calculated with the program Clam 2.2 using linear interpolation between dates (Blaauw 2010). The final model output runs within the $2 \sigma$ confidence envelope of a generalized mixed-effect regression (GAM, Heegaard et al. 2005) and the $95 \%(2 \sigma)$ probabilities of the calibrated radiocarbon ages (Fig. 2).

\section{Pollen, spores, non-pollen palynomorphs, microscopic charcoal, and macrofossil analysis}

A total number of 109 subsamples for pollen, spores, nonpollen palynomorphs (NPPs), and microscopic charcoal 
Table 1 Radiocarbon dates, calibrated ages, and pollen-inferred age from the Lac de Champex record. Uncertainties of ${ }^{14} \mathrm{C}$ ages refer to $68 \%$ probabilities $(1 \sigma)$ whereas ranges of calibrated and modelled ages represent $95 \%$ probabilities $(2 \sigma)$

\begin{tabular}{|c|c|c|c|c|c|c|}
\hline Code & Depth $[\mathrm{cm}]$ & Material/ Comments & $\begin{array}{l}{ }^{14} \mathrm{C} \text { age } \\
(\mathrm{BP})^{\mathrm{a}}\end{array}$ & $\begin{array}{l}\text { Median age } \\
\left(\text { cal вP) }{ }^{b}\right.\end{array}$ & $\begin{array}{l}\text { Age } 2 \sigma \text { range } \\
(\text { cal вP) })^{b}\end{array}$ & $\begin{array}{l}\text { Modelled age } \\
(\text { cal вР })^{\mathrm{c}}\end{array}$ \\
\hline BE-10044.1.1 & $105-106$ & Anther indet, bud scale indet, needles indet & $1,915 \pm 30$ & 1,830 & $1,740-1,925$ & - (rejected) \\
\hline BE-10045.1.1 & $124.5-125.5$ & Needles indet, seed indet & $1,920 \pm 20$ & 1,840 & $1,745-1,915$ & - (rejected) \\
\hline BE-10046.1.1 & $166-167$ & Needles indet & $995 \pm 40$ & 880 & $790-960$ & 845 \\
\hline BE-5979.1.1 & $193-195$ & Larix decidua needles & $1,045 \pm 20$ & 945 & $920-970$ & 945 \\
\hline BE-5980.1.1 & $217-219$ & Picea abies seed & $1,925 \pm 20$ & 1,845 & $1,745-1,920$ & 1,850 \\
\hline BE-5981.1.1 & $237-239$ & P. abies twig & $2,915 \pm 30$ & 3,055 & $2,965-3,160$ & 3,050 \\
\hline BE-5982.1.1 & $267-269$ & Abies alba needles, Pinus sylvestris needles & $3,715 \pm 20$ & 4,040 & $3,985-4,145$ & 4,035 \\
\hline BE-5983.1.1 & $293-295$ & A. alba seed, A. alba seed wing & $4,515 \pm 20$ & 5,150 & $5,050-5,305$ & 5,145 \\
\hline BE-6997.1.1 & $315-317$ & A. alba cone scale & $5,285 \pm 20$ & 6,085 & $5,950-6,180$ & 6,085 \\
\hline BE-6998.1.1 & $335-337$ & A. alba needles, L. decidua remains & $6,010 \pm 20$ & 6,850 & $6,785-6,935$ & 6,845 \\
\hline BE-6999.1.1 & $347-349$ & A. alba needle, $P$. sylvestris cone scale & $6,280 \pm 20$ & 7,215 & $7,165-7,255$ & 7,215 \\
\hline BE-7000.1.1 & $363-365$ & P. sylvestris cone scale, leaf fragments & $6,975 \pm 20$ & 7,810 & $7,725-7,920$ & 7,805 \\
\hline BE-7001.1.1 & $389-391$ & Leaf fragments, terrestrial plant remains & $7,705 \pm 50$ & 8,485 & $8,405-8,590$ & 8,490 \\
\hline BE-7002.1.1 & $411-413$ & Betula fruit, bud scale indet, periderm indet & $8,815 \pm 25$ & 9,840 & $9,695-10,120$ & 9,830 \\
\hline BE-5984.1.1 & $430.5-431.5$ & Betula fruits, deciduous bud & $9,640 \pm 25$ & 11,030 & $10,800-11,180$ & 11,035 \\
\hline LST & 449.5 & Laacher See Tephra & - & $13,035^{\mathrm{d}}$ & $12,885-13,185^{\mathrm{d}}$ & 13,025 \\
\hline Mid Bølling & 472 & Pollen-inferred age (Juniperus and Betula trend) & - & $14,440^{\mathrm{d}}$ & - & 14,435 \\
\hline
\end{tabular}

${ }^{\text {a }}$ Stuiver and Polach (1977)

${ }^{\mathrm{b}}$ Reimer et al. (2020)

${ }^{\mathrm{c}}$ Blaauw (2010)

${ }^{\mathrm{d}}$ van Raden et al. (2013)

LSTLaacher See Tephra, indet indeterminable

analysis were retrieved from the sediment core. The sampling volume was $1 \mathrm{~cm}^{3}$ for each subsample. 81 subsamples were evenly taken along the core (i.e. every 2,4 or
$16 \mathrm{~cm}$ depending on the sedimentation rate). The remaining 28 subsamples were taken continuously from 222 to $194 \mathrm{~cm}$ (Late Iron Age to Early Medieval period high
Fig. 2 Age-depth model and lithology of Lac de Champex. Black dots show the calibrated ages with $95 \%(2 \sigma)$ probabilities (IntCal20, Reimer et al. 2020). The two topmost ages (dark grey crosses) are outliers. The empty black square in the bottom marks one additional pollen-inferred age (mid-Bølling). The black line is the modelled chronology (linear interpolation with the program clam 2.3, Blaauw 2010). The grey lines represent the $95 \%(2 \sigma)$ probabilities of a generalized mixedeffect regression model applied to the record (GAM, Heegaard et al. 2005). LST Laacher See Tephra (black star)

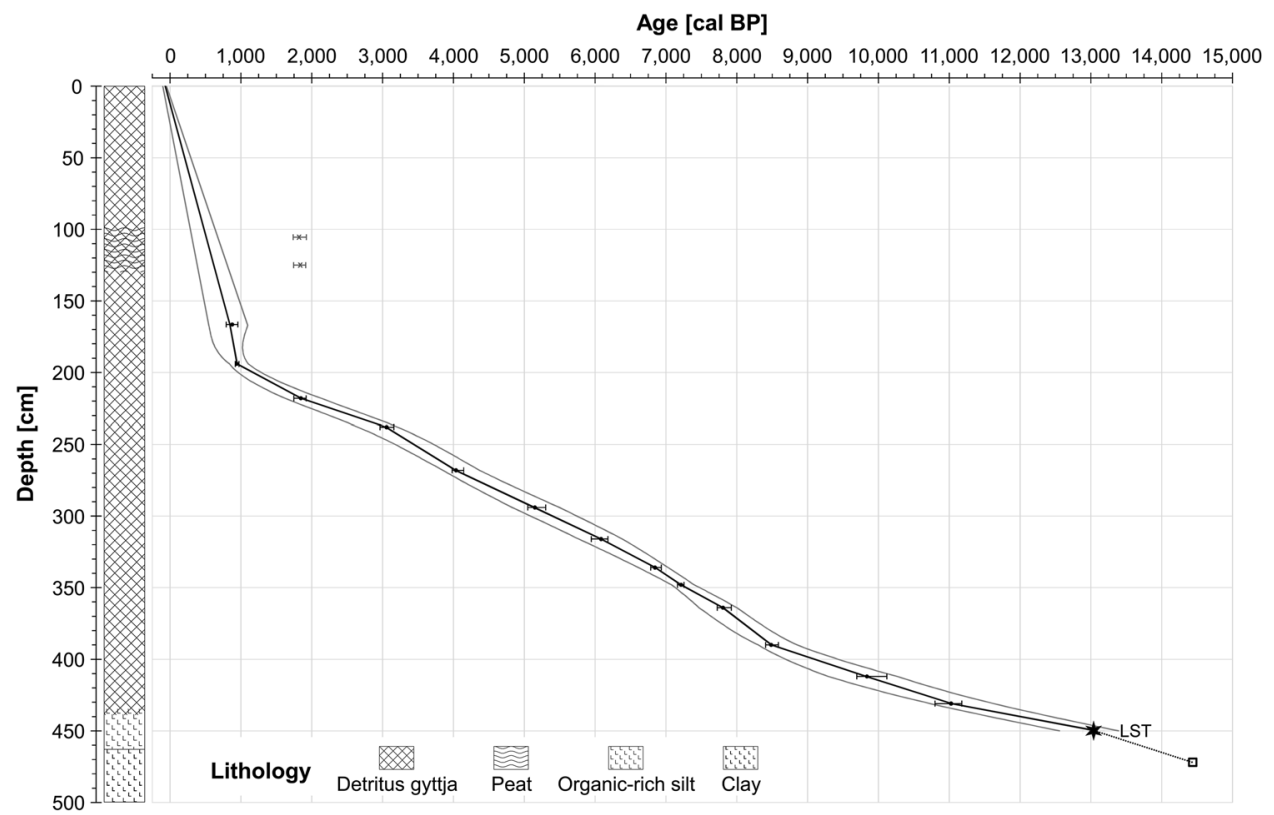


resolution interval). All palynological subsamples were chemically treated with $10 \% \mathrm{HCl}, 10 \% \mathrm{KOH}, 40 \% \mathrm{HF}$ and acetolysis, sieved through a mesh size of $0.5 \mathrm{~mm}$ and mounted in glycerine following standard preparation protocols (Moore et al. 1991). Lycopodium tablets (University of Lund batch no. 3862 with 9,666 spores per tablet) were added prior to the chemical treatment to estimate pollen, spore, NPP and microscopic charcoal concentrations (Stockmarr 1971). Pollen and spores were identified under a light microscope (Leica, Germany) at $400 \times$ magnification using photo atlases (Reille 1992) and palynological keys (Moore et al. 1991; Beug 2004). 129 different pollen types were found and generally pollen sums of $>500$ were reached ( $>350$ for three samples from the bottom of the sediment core below $462 \mathrm{~cm}$ ). No subsamples were analysed below $472 \mathrm{~cm}$ due to very low pollen concentrations. The pollen record (Fig. 3) was separated into local pollen assemblage zones (LPAZ) inferred by optimal sum-of-squares partitioning (Birks and Gordon 1985). Four statistically significant zones were identified using the broken stick model following Bennett (1996). For discussion/presentation of the results, LPAZ CHX-2 was split into three additional subzones, and CHX-3 and CHX-4 were split into two subzones. All these subzones were not statistically significant. The pollen results are presented in percentages calculated based on the terrestrial pollen sum (Figs. 3 and 4). Cannabis sativa was excluded from the terrestrial pollen sum to avoid possible artificial pollen input from hemp retting influencing the percentage abundances. The various coniferous stomata were identified following Trautmann 1953 and Finsinger and Tinner 2020. Stomata are presented as presence / absence (Fig. 3). Microscopic charcoal particles $>10 \mu \mathrm{m}$ were counted following Tinner and $\mathrm{Hu}$ (2003) and Finsinger and Tinner (2005). The results of microscopic charcoal and spores as well as the NPP counts are presented as influx (particles/spores $\mathrm{cm}^{-2} \mathrm{yr}^{-1}$, Fig. 3).

121 subsamples for macrofossil analysis were taken along the sediment core. The uppermost $191 \mathrm{~cm}$ and the bottom part (below $472 \mathrm{~cm}$ ) of the sediment sequence were not systematically analysed. A sieve with $200 \mu \mathrm{m}$ mesh width was used to separate the macrofossils from the fine-grained sediment. The macrofossils were identified under a stereomicroscope with the help of keys (e.g. Schoch et al. 1988) and the reference collection at the Institute of Plant Sciences of University of Bern. The calculated macrofossil concentrations are based on a standard volume of $9 \mathrm{~cm}^{3}$. For better comparison, the same zonation as for the pollen results (LPAZ) was used for the macrofossil record (Fig. 5). All pollen and macrofossil figures were plotted in Tilia 2.0.60 and finalized in CorelDraw.

\section{Quantitative analyses}

Rarefaction analysis (Birks and Line 1992) was applied to assess the palynological richness (PRI). The calculations are based on the lowest terrestrial pollen count, which was 360 pollen grains at $462 \mathrm{~cm}$ sediment depth. Subsequently, the probability of interspecific encounter (PIE, Hurlbert 1971) as measure of palynological evenness and evennessdetrended palynological richness (DE-PRI) were calculated following Colombaroli and Tinner (2013). PRI and DE-PRI are given as number of different pollen types per counted 360 pollen grains and PIE as probability index (0-1, Fig. 3 ).

Ordination analysis was implemented to identify trajectories in vegetation composition over time (Birks and Gordon 1985; ter Braak and Prentice 1988). We chose a detrended correspondence analysis (DCA, Birks and Gordon 1985) with detrending by segments and without down-weighting of rare species for our model calculations (length of first axis 2.01 SD units; Fig. 3 and ESM). Finally, we calculated correlation coefficients to test for significant relationships between microscopic charcoal and selected pollen types. A $t$-test was applied to investigate whether the correlation coefficients differ significantly from $0(\mathrm{r} \neq 0, \alpha=5 \%$, two-sided, Bahrenberg et al. 2008). The selected time window for the analysis was the Late Iron Age to the Early Medieval (ca. 2,100-950 cal BP, Figs. 4 and 6). The vegetation composition for this time period was relatively stable indicating no major trends that could have affected the correlation calculations. All statistical analyses were conducted in R (R Development Core Team 2020), Canoco 5 (Šmilauer and Lepš 2014) and MYSTAT 12 (student version of SYSTAT 12).

\section{Results and interpretation}

\section{Lithology and chronology}

The bottom of the sediment core (below $463 \mathrm{~cm}$ ) consists of silty clay. The sediment then changes to organic-rich silt until $439 \mathrm{~cm}$. According to the age-depth model (Fig. 2), the sedimentation rate was low (ca. $50 \mathrm{yrs} \mathrm{cm}^{-1}$ ) in this bottom part of the sediment sequence. After a short transition of $4 \mathrm{~cm}$, the sediment consists of gyttja. The sedimentation rate remains very low and stable. Only for the uppermost ca. $190 \mathrm{~cm}$, there is a steep increase of the sedimentation rate (ca. $5 \mathrm{yrs} \mathrm{cm}^{-1}$ ) probably due to higher erosional input from the Middle Ages onward. Between 130 and $99 \mathrm{~cm}$ depth, the sediment is moderately enriched by peat material. The two rejected radiocarbon dates fall exactly into this peaty layer. Most likely, the peat and old plant material preserved therein was washed into the lake during the construction of the water channel and possibly peat cutting during the Middle Ages. Hence, the too old ages of the two outlying 


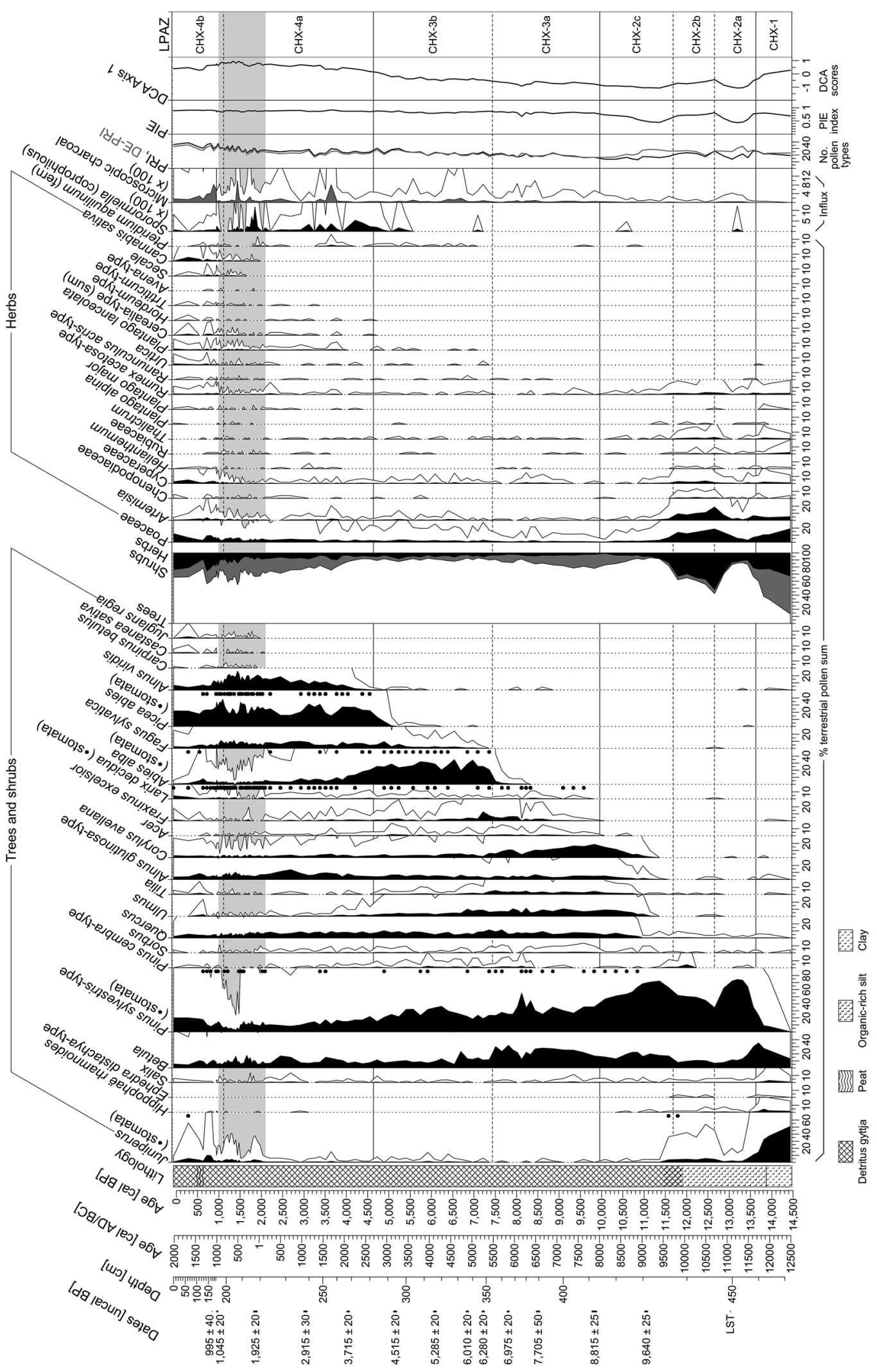


4Fig. 3 Lac de Champex sediment sequence and pollen record. Presented are the radiocarbon dates, the lithology, percentages of selected pollen types and Pteridium aquilinum (fern spores), presence of stomata (black dots), microscopic charcoal and Sporormiella (coprophilous fungal spores) influx values (particles/ spores $\mathrm{cm}^{-2} \mathrm{yr}^{-1}$ ), the palynological richness (PRI; black line), the evenness-detrended palynological richness (DE-PRI; dark grey line), the palynological evenness (PIE) as well as the detrended correspondence analysis (DCA) axis 1 scores. Empty curves represent the $10 \times$ exaggerations. LST Laacher See Tephra, LPAZ local pollen assemblage zones. The light grey bar marks the position of the high-resolution section of the record shown in Fig. 4

radiocarbon dates are probably a result of reworking processes and need to be rejected.

\section{Vegetation and fire history}

The pollen and macrofossil diagrams (Figs. 3 and 5) are subdivided into four statistically significant LPAZ. Four statistically not significant zone boundaries delimit additional subzones (CHX-2a, 2b, 2c, 3a, 3b, 4a and 4b).

\section{CHX-1 (14,500-13,620 cal BP), Juniperus-Betula-Poaceae LPAZ}

Pollen of herbs (Poaceae, Artemisia, Helianthemum, Rubiaceae and Thalictrum) and shrubs (Juniperus, Hippophä̈ rhamnoides, Ephedra distachya-type and Salix) dominates with values up to $90 \%$. The pollen assemblage suggests the establishment of pioneer vegetation shortly after the site had become ice-free. The most frequent tree pollen is Betula, which is increasing from 10 to $30 \%$ throughout the zone. This trend is supported by regular finds of Betula fruits (from ca. 14,000 cal BP onwards), indicating local occurrence of birch trees close to the lake at the onset of the Allerød (13,900 cal BP, van Raden et al. 2013). Microscopic charcoal influx values are very low $\left(<40\right.$ particles $\left.\mathrm{cm}^{-2} \mathrm{yr}^{-1}\right)$ and macroscopic charcoal pieces are absent, suggesting scarce regional and local fire activity.

\section{CHX-2a $(13,620-12,770$ cal BP), Pinus-Betula sub-LPAZ}

The onset of this subzone is marked by a sharp increase of tree pollen percentages (up to 90\%) mainly resulting from $P$. sylvestris-type. The dominance of $P$. sylvestris-type pollen is underlined by a single pine bud scale find, which may indicate the occurrence of pine trees not far from the site. Meanwhile, pollen percentages of shrubs and herbs are first decreasing and then markedly increase again (up to $55 \%$ ) towards the end of the subzone. At the same time, no more plant macrofossils occur in the record, which is likely related to a drop of the tree line below the site as a result of the Younger Dryas cooling after 12,700 cal вP, as inferred from the strong arboreal pollen (AP) decline (from $>80 \%$ to $>60 \%$ ). The charcoal values are slightly increasing (microscopic charcoal influx up to 220 particles $\mathrm{cm}^{-2} \mathrm{yr}^{-1}$ ), which could point to a higher fire activity due to increased fuel availability.

\section{CHX-2b (12,770-11,690 cal вP), Pinus-Poaceae-Artemisia sub-LPAZ}

Open vegetation dominated in the area around the lake in this subzone as indicated by fairly high herb pollen percentages (35-55\%). The most common herbaceous taxa are Poaceae (around 15\%) and Artemisia (around 10\%). Juniperus pollen percentages are at 5\% whereas P. sylvestris-type values decrease to $40-50 \%$. A first stoma of Juniperus in the upper part of the subzone may indicate the re-colonization of the area around the lake by the first shrubs at the end of the Younger Dryas at ca. 11,800 cal BP. Microscopic charcoal influx drops again $\left(<80\right.$ particles $\left.\mathrm{cm}^{-2} \mathrm{yr}^{-1}\right)$, suggesting lower fire activity as a consequence of lower fuel availability.

\section{CHX-2c (11,690-9,960 cal вP), Pinus-Betula sub-LPAZ}

The presence of plant macrofossils from Betula and $P$. sylvestris, Pinus stomata as well as increased pollen percentages of Betula (up to 20\%) and P. sylvestris-type (up to $70 \%$ ) indicate that forests recovered shortly after $11,500 \mathrm{cal}$ $\mathrm{BP}$ in response to climate warming at the beginning of the Holocene (e.g. Heiri et al. 2014, 2015). Pollen of temperate trees and shrubs (Alnus glutinosa-type, Corylus avellana, Quercus, Tilia, Ulmus) either occur for the first time or increase, indicating the establishment of temperate deciduous forest in the lowlands, while macrofossil evidence for a local presence at the site (e.g. bud scales) is lacking. Microscopic charcoal shows an increase (up to 275 particles $\mathrm{cm}^{-2} \mathrm{yr}^{-1}$ ) and this trend is underlined by regular finds of macroscopic charcoal, together suggesting higher regional and local fire activity, which was probably related to the continental climate in the Early Holocene, with warm and dry summers as well as increased fuel biomass (Tinner and Lotter 2001; Heiri et al. 2014).

\section{CHX-3a $(9,960-7,470$ cal BP), Pinus-Betula-Larix decidua sub-LPAZ}

Pollen percentages of Betula and P. sylvestris-type show similar values (around 30\%). Together with regular finds of Betula and Pinus sylvestris macrofossils, they indicate that mixed pine-birch forests prevailed around Lac de Champex. At the same time, pollen percentages from temperate deciduous species are highest (e.g. $20 \%$ for $C$. avellana), and $L$. decidua pollen as well as Fraxinus excelsior pollen occurs for the first time. Regular finds of L. decidua macrofossils and stomata are indicative of the spread of larch trees into 
Fig. 4 Lac de Champex high resolution section. Presented are the percentages of selected pollen types, microscopic charcoal and Sporormiella (coprophilous fungal spores) influx values (particles/ spores $\mathrm{cm}^{-2} \mathrm{yr}^{-1}$ ) and the palynological richness (PRI). Empty curves represent the $10 \times$ exaggerations

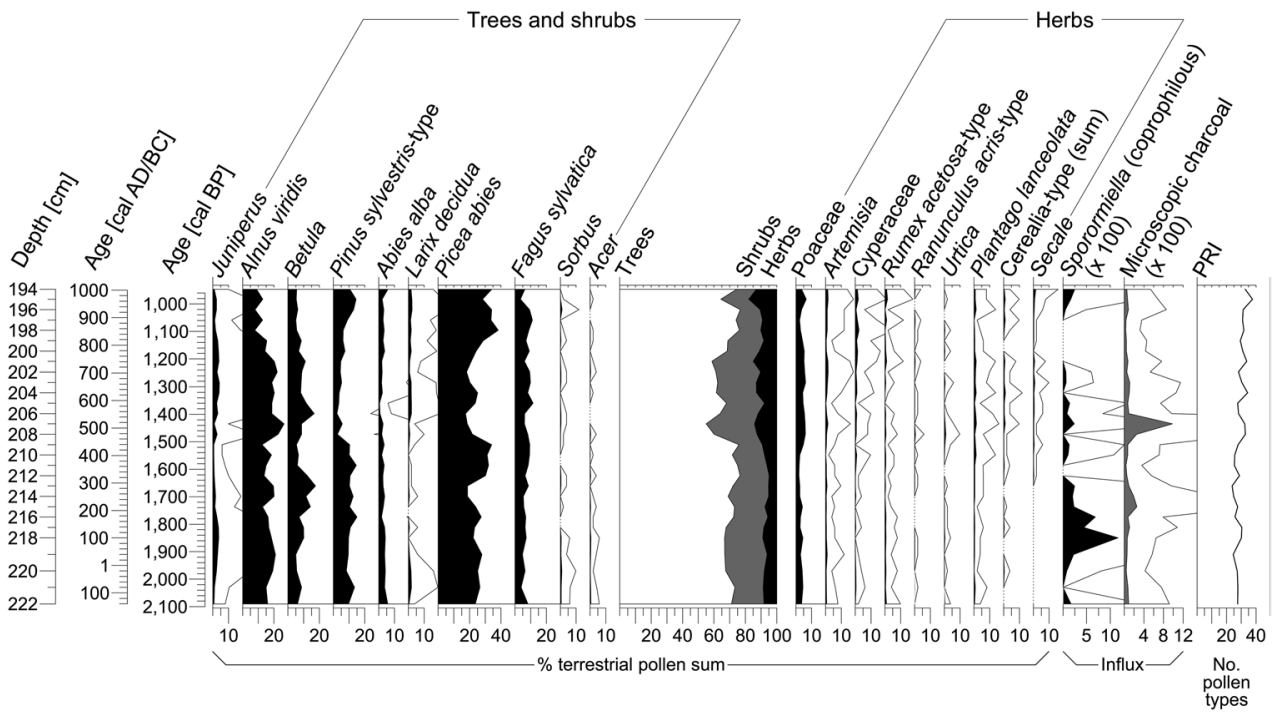

the mixed pine-birch forests. In the upper part of the subzone, A. alba pollen and macrofossils appear for the first time, suggesting that silver fir trees established regionally at around 8,200 cal BP (empirical pollen limit) and locally at ca. 7,500 cal BP (first macrofossils). Charcoal influx values fluctuate around 300 particles $\mathrm{cm}^{-2} \mathrm{yr}^{-1}$ and macroscopic charcoal pieces occur only sporadically. Hence, local fires became less frequent, whereas the regional fire activity remained at a high level. Moisture availability increases could be the reason for this shift in the fire regime, with lower flammability of the forests around the lake resulting from increased orographic precipitation.

\section{CHX-3b $(7,470-4,630$ cal вP), Abies alba-Pinus-Larix decidua sub-LPAZ}

Abies alba became the dominant tree in the forests as indicated by pollen percentages reaching almost $40 \%$, numerous stomata as well as macrofossil finds. Plant remains of $L$. decidua are more frequent as well, suggesting a co-dominance of larch trees in the forests. An Acer bud scale and some Betula fruits indicate that deciduous trees were present too. P. abies and A. viridis pollen reach their empirical limits at 6,000 and 5,500 cal BP respectively, suggesting first establishment of stands in the Champex area. At ca. 7,000 cal вР (5050 cal вC), Plantago lanceolata pollen appears in the pollen sequence, documenting the onset of agricultural activities close to the site. Pastoral farming was intensified after 5,500 cal вР (3550 cal вC) as indicated by higher local fire activity (continuous macroscopic charcoal curve) and frequent finds of Sporormiella (coprophilous fungal spore), a proxy for livestock farming (Rey et al. 2013; Schwörer et al. 2015). P. abies pollen percentages start to rise contemporaneously while $A$. alba percentages are decreasing, announcing the next pronounced change in forest composition.

\section{CHX-4a (4,630-1,120 cal вP), Picea abies-Alnus viridis-Larix decidua sub-LPAZ}

Picea abies pollen becomes dominant (values up to $30 \%$ ) while A. alba pollen percentages are massively decreasing $(<5 \%)$. In contrast, disturbance-adapted A. viridis was spreading in the area, as indicated by rising pollen percentages (up to 20\%). Numerous finds of L. decidua stomata and macrofossils suggest that larch could cope with the generally increased disturbance and remained an important element in the forests. Continuous curves of P. lanceolata and Cerealia-type pollen as well as peaks of Sporormiella fungal spores suggest pastoral and arable farming activities close to the lake (also see Fig. 4). This general trend towards intensified land use is supported by maximum charcoal values (microscopic charcoal up to 2,300 particles $\mathrm{cm}^{-2} \mathrm{yr}^{-1}$ and continuous macroscopic charcoal curve) indicating higher fire activity likely originating from repeated regional to local slash-and-burn activities.

\section{CHX-4b (1,120 cal BP-modern times), Picea abies-Poaceae-Larix decidua sub-LPAZ}

This subzone delimits the last millennium with the most intense land use. The pollen and stomata records suggest that the surrounding forest was still composed of mainly $P$. abies and $L$. decidua, with a few $P$. sylvestris. Alnus viridis shrublands were replaced by open grasslands as indicated by the pollen percentages (herbaceous pollen up to $20 \%$ ). Human indicator pollen ( $P$. lanceolata, Cerealia-type, Secale, Cannabis sativa) occurs frequently and shows mostly closed curves, underlining the ongoingagricultural activities close 


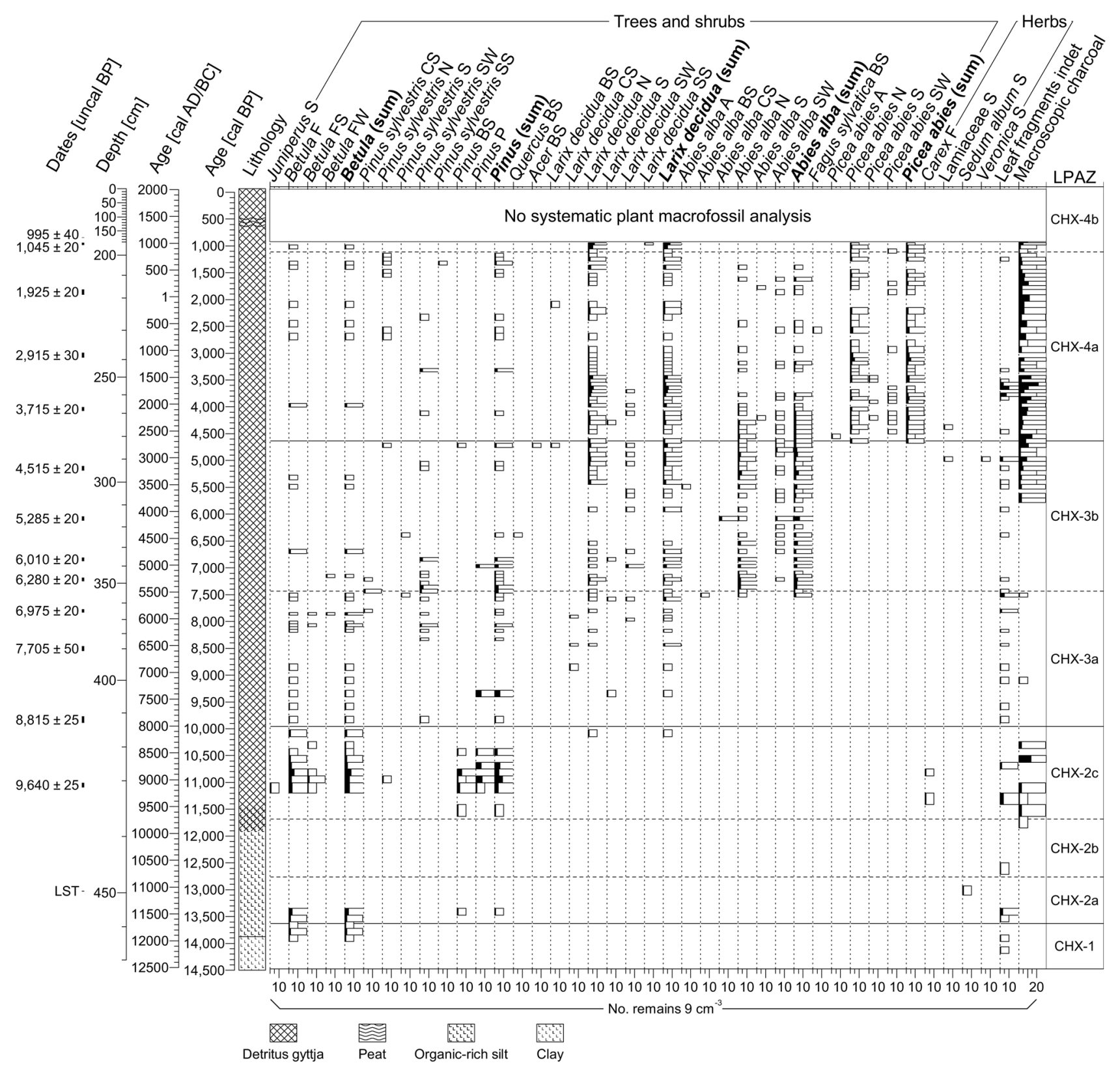

Fig. 5 Lac de Champex sediment sequence and macrofossil record. Presented are the radiocarbon dates, the lithology, concentrations (number of remains per $9 \mathrm{~cm}^{3}$ ) of selected plant macrofossils and macroscopic charcoal (particles $\geq 200 \mu \mathrm{m}$ ). Empty curves represent the $10 \times$ exaggerations. The uppermost ca. $190 \mathrm{~cm}$ of the sediment

to the lake. A last pronounced microscopic charcoal peak at 880 cal BP (cal AD 1070) corresponds to a phase with the highest herb pollen percentages, suggesting that fires were used to remove shrubs and trees to keep the landscape open.

\section{Quantitative analyses}

The diversity estimates are very stable at around 20-30 taxa per sample throughout the record (Fig. 3). The numbers are core have not been analyzed. LST Laacher See Tephra, LPAZ local pollen assemblage zones, indet indeterminable, $A$ anther, $B S$ bud scale, $C S$ cone scale, $F$ fruit, $F S$ fruit scale, $F W$ fruit wing, $N$ needle, $P$ periderm, $S$ seed, $S S$ short shoot, $S W$ seed wing

slightly higher (at 30 taxa per sample) after 2,000 cal BP, which is related to the intensified land-use and the introduction of new crops in the region (e.g. Juglans regia, Secale). The difference between PRI and DE-PRI is generally small, indicating that PRI is not much affected by evenness effects. $\mathrm{PIE}<0.6$ is recorded from 13,500 to 13,000 cal BP and from 11,500 to $11,000 \mathrm{cal} \mathrm{BP}$, when $P$. sylvestris pollen grains are dominant ( $\geq 70 \%$ of the terrestrial pollen sum). Here, DEPRI is notably higher than PRI which points to evenness 
Fig. 6 Correlogram showing the correlation coefficients between microscopic charcoal influx and selected pollen types, Sporormiella and palynological richness (PRI) for the period $2,100-950$ cal вP (150 BC-AD 1000, Fig. 4). The dotted lines mark the significance level $(P=0.05)$

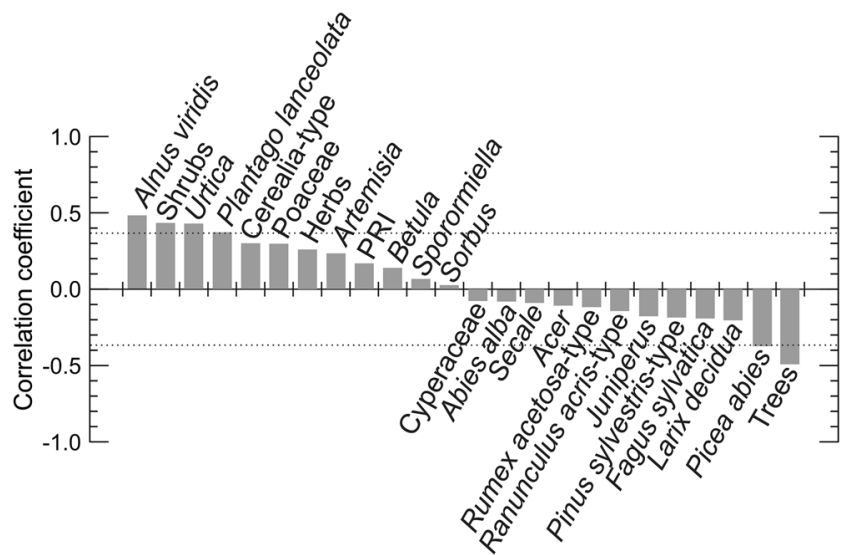

13,900-12,700 cal BP, Ammann et al. 2013; Rach et al. 2014), which is confirmed by macrofossils from P. sylvestris and Betula at Lac de Champex and Pinus stomata at Zeneggen-Hellelen (Welten 1982b). The tree line may have even reached 2,000 $\mathrm{m}$ a.s.l. during the Allerød, as indicated by a few Betula fruits at Simplon-Hobschensee (2,018 m a.s.l., Lang and Tobolski 1985). However, these results must be interpreted with caution since strong and channelled wind close to the Simplon pass may have transported the rather light and winged Betula fruits from lower altitudes. Nevertheless, it could well be that birch stands could have grown just below 2,000 $\mathrm{m}$ a.s.l. setting the tree line a few hundred metres above Lac de Champex at 1,700-1,800 m a.s.l. This would agree well with the results from the Eastern Central Alps in the Lower Engadine, where Welten (1982a) found Pinus stomata at Schwarzsee (1,726 m a.s.l.) but none at Grünsee (1,836 $\mathrm{m}$ a.s.1.). Likewise, a tree line position as high as 1,700 m a.s.l. is documented in the Southern Alps during the Allerød as indicated by high concentrations of Larix needles and stomata at Totenmoos $(1,718 \mathrm{~m}$ a.s.1., Heiss et al. 2005). Hence, a rise of the tree line from 800 to $1,000 \mathrm{~m}$ a.s.l. up to ca. $1,700 \mathrm{~m}$ a.s.l. in parts of the Southern and Central Alps during the Allerød warming is very likely (Vescovi et al. 2007, 2018). In contrast, the tree line in the Northern Alps, which are particularly prone to cold air intrusions from persisting ice caps in the North, must have been 300-400 m lower, not exceeding 1,400 m a.s.l. (Rey et al. 2013; Heiri et al. 2014).

During the Younger Dryas cooling (ca. 12,700-11,600 cal BP), Lac de Champex was not reached by re-advancing glaciers, comparable to many other sites in the Alps below 2,000 m a.s.l. (Welten 1982a, b; Lang and Tobolski 1985; Pini 2002; Heiss et al. 2005; Ilyashuk et al. 2009; Rey et al. 2013). The lack of tree macrofossil and stomata finds at our site as well as in the records from Zeneggen-Hellelen (Welten 1982b) and Simplon-Hobschensee (Lang and Tobolski 1985) and the expansion of alpine herbs indicate a drop of the tree line in the Central Alps below 1,400 m 
a.s.l. However, the exact position of the tree line during the Younger Dryas is not clear, since suitable sites between the valley bottom and 1,400 $\mathrm{m}$ a.s.l. are lacking. The forests around many sites in the central alpine valleys and in the lowlands south and north of the Alps became rather open again (Welten 1982a, b; Vescovi et al. 2007; Colombaroli et al. 2013; Rey et al. 2017, 2020). In the Southern Alps, trees were present at Pian di Gembro (1,350 m a.s.l., Pini 2002) whereas treeless tundra vegetation was re-expanding at Foppe (1,470 $\mathrm{m}$ a.s.1., Vescovi et al. 2018), setting the tree line somewhere around 1,400 $\mathrm{m}$ a.s.l. North of the Alps, trees could grow at least up to $925 \mathrm{~m}$ a.s.l. as indicated by the record from Chutti (Welten 1982b). Thus, a central alpine tree line position around $1,000-1,400 \mathrm{~m}$ a.s.l. is very realistic, resulting in a lowering of the tree line by ca. $300-800 \mathrm{~m}$ during the Younger Dryas.

Reforestation at Lac de Champex started shortly after the end of the Younger Dryas between 11,500 and 11,200 cal вP with P. sylvestris and Betula, which agrees with the results from Zeneggen-Hellelen (1,510 m a.s.l., Welten 1982b). At Gouillé Rion (2,343 m a.s.1.), first macrofossils of trees were recorded already at 11,350 cal вр (Tinner and Kaltenrieder 2005). Hence, the rapid warming by about $4{ }^{\circ} \mathrm{C}$ (Schwander et al. 2000) at the onset of the Holocene was associated with a sudden upwards shift of the tree line by almost $1,000 \mathrm{~m}$ within a few centuries. This rapid afforestation of high elevations is recorded in many other sites in the Central and Southern Alps (Lang and Tobolski 1985; Wick and Tinner 1997; Gobet et al. 2005; Finsinger and Tinner 2007; Valsecchi and Tinner 2010). In contrast, the afforestation at higher elevations was delayed in the Northern Alps by almost 1,500 years, which is a regional phenomenon seen at many sites (e.g. Wick et al. 2003; Lotter et al. 2006) and is possibly caused by strong decreases in summer temperatures during the Preboreal Oscillation (11,350-11,100 cal BP), higher seasonality, and cold air spells from the North (Schwörer et al. 2014; Thöle et al. 2016).

After 10,000 cal вP, L. decidua expanded into the mixed pine-birch forests around Lac de Champex. The high summer temperatures during the Holocene Thermal Maximum (HTM, Heiri et al. 2015) may even have favoured the expansion of temperate trees such as Quercus, Tilia, Ulmus and Acer as documented by single macrofossil finds at Lac de Champex and even at higher elevation at Lac de Bretaye (1,780 m a.s.l., Thöle et al. 2016). Mixed pine-birch-larch forests prevailed until ca. 7,500 cal BP, when A. alba started to expand locally, while regionally it expanded earlier, around 8,200 cal BP. The spread of mesophilous A. alba and F. sylvatica at lower elevations was caused by a climatic shift towards more oceanic conditions with higher precipitation after the 8.2 ka event (Tinner and Lotter 2001, 2006), which is recorded as lake level rises on the western Swiss Plateau, in eastern France and in the Jura Mountains (Magny et al.
2011; Magny 2013). The expansion of Abies alba at higher altitudes after 7,500 cal BP is well-documented across the Western and Northern Alps (Heiri et al. 2003; Tinner and Kaltenrieder 2005; Rey et al. 2013; Schwörer et al. 2014; Thöle et al. 2016) and the lowlands north of the Alps (Lotter 1999; Becker et al. 2006; Wehrli et al. 2007; Gobet and Tinner 2012; Gobet et al. 2017; Rey et al. 2017, 2020). Based on macrofossil data, the highest regional tree line was located at ca. 2,530 m a.s.l. during the HTM between 7,000 and $5,000 \mathrm{cal}$ вр (Tinner and Theurillat 2003). At the same time, the maximum tree line position was at about 2,250 $\mathrm{m}$ a.s.l. in the Northern Alps (Berthel et al. 2012; Heiri et al. 2014).

The onset of the massive P. abies expansion at 5,000 cal BP and the subsequent replacement of mixed A. alba forests after 4,500 cal BP is typical for the Valais and well-documented at many sites (Welten 1982b; Tinner and Theurillat 2003; Finsinger and Tinner 2007). The spread of $P$. abies around Lac de Champex coincides with high abundances of coprophilous Sporormiella fungal spores, which are a common proxy for grazing (e.g. Rey et al. 2013; Schwörer et al. 2014; Dietre et al. 2020). Therefore, increased pastoral activities might have facilitated the mass expansion of $P$. abies in the region, by negatively affecting disturbancesensitive $A$. alba, which at these altitudes occupies similar ecological habitats. The establishment of $P$. abies in the Valais occurred at a similar time as at sites in the Northern Alps at ca. 6,000 cal вр (Tinner and Theurillat 2003; Rey et al. 2013; Schwörer et al. 2014, 2015; Thöle et al. 2016). However, the massive spread of the species in the Valais was somewhat delayed by 500 years compared to the Northern Alps, possibly due to limited moisture availability (Henne et al. 2011). Indeed, the Valais is characterized by a continental climate with rather dry summers (summer precipitation $<250 \mathrm{~mm}$, Landolt et al. 2015), which might have favoured the deep-rooting but disturbance-intolerant A. alba compared to shallow-rooting and relatively drought-sensitive P. abies (Henne et al. 2011; Tinner et al. 2013), and allowed the species to persist longer than in the Northern Alps.

Our pollen record indicates the steady expansion of $A$. viridis thickets after $4,000 \mathrm{cal} \mathrm{BP}$, which is in agreement with many sites in the Alps (Welten 1982a, b; Wick and Tinner 1997; Gobet et al. 2003; Tinner and Theurillat 2003; Wick et al. 2003; Lotter et al. 2006; Rey et al. 2013; Schwörer et al. 2014). Disturbance-adapted A. viridis seemed to have benefited from the intensified disturbance (i.e. fires and anthropogenic forest clearings) since the Bronze Age. Indeed, significant positive correlations between macroscopic charcoal influx and $A$. viridis percentages are recorded for the period 2,100-950 cal вр, whereas trees (including $P$. abies) suffered at the same time (Fig. 6). The most intense forest disruptions at Lac de Champex were recorded during the last 1,000 years. However, compared to sites at or just below the present-day tree line (e.g. Tinner and Theurillat 2003; 
Lotter et al. 2006; Schwörer et al. 2014), the forest openings at Lac de Champex remained quite small, suggesting that some forests at mid altitudes were less affected by land use, a finding which is confirmed by the results from Hinterburgsee in the northern Swiss Alps (1,515 m a.s.l., Heiri et al. 2003).

\section{Land use history since 7,000 cal BP}

Numerous archaeological finds in the region (Figs. 1 and 7) indicate human presence since the Mesolithic (ca. 9,450 cal BP, 7500 cal вс). The Mesolithic site Pathiéfray close to the village Verbier is a good example of a seasonal camp or shelter probably used by hunters (Taramarcaz and Curdy 2013). However, those people hardly modified the vegetation in a way that could be traced in palaeoecological records. The first signs of human land use around Lac de Champex are documented by cultural indicators such as $P$. lanceolata and Sporormiella around 7,000 cal вр (5050 cal вС). In agreement, regional archaeological finds indicate a first spread of permanent settlements of early farmers from the main Rhône Valley into Val d'Entremont during the Middle Neolithic (6,650-5,050 cal вр, 4700-3100 cal вС; Wermus 1981; Curdy 2007). The colonization of side valleys took place during a period of favourable warm and dry climate (Haas et al. 1998; Gobet et al. 2003; Rey et al. 2019a). The known settlements are all located in the valley bottoms, not exceeding 1,000 $\mathrm{m}$ a.s.l. (Curdy 2007). However, the higher altitudes were most likely occupied at least seasonally for

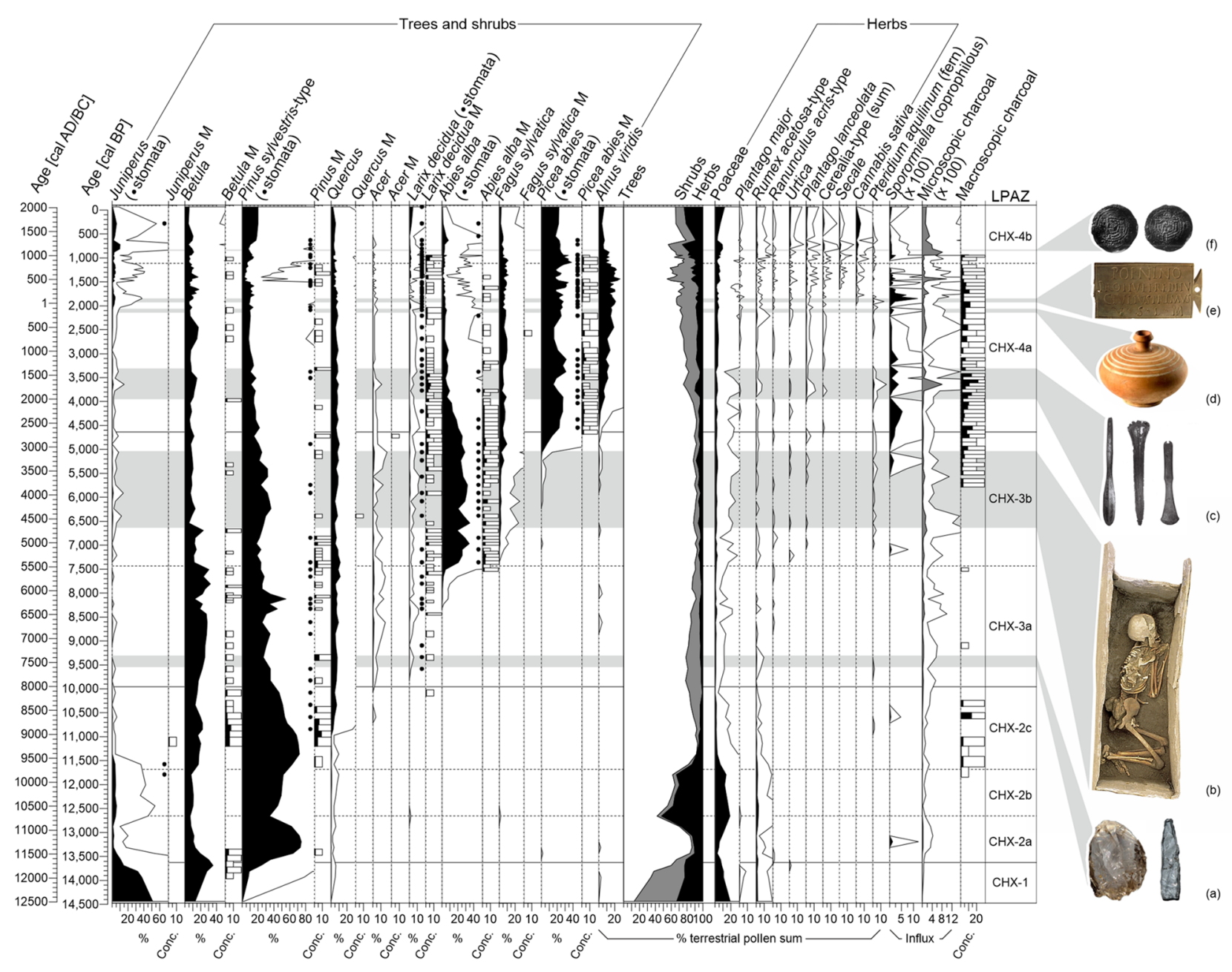

Fig. 7 Composite of the percentages of selected pollen types, microscopic charcoal and Sporormiella influx values (particles/ spores $\mathrm{cm}^{-2} \mathrm{yr}^{-1}$ ), plant macrofossil and macroscopic charcoal concentrations (number of remains per $9 \mathrm{~cm}^{3}, \geq 200 \mu \mathrm{m}$ ) and the regional archaeology (grey horizontal bars). Empty curves represent the $10 \times$ exaggerations. $L P A Z$ local pollen assemblage zones, $M$ macrofossils (sum). (a) Formed crystal rocks from the Mesolithic (ca. 76007400 BP, Verbier La Chaux "Pathiéfray", Taramarcaz and Curdy
2013), (b) Middle Neolithic grave (ca. 4700-3100 BC, Sembrancher "Crettaz-Polet", Wermus 1981), (c) Short axe, sword and axe from the Early and Middle Bronze Age (ca. 2000-1350 BC, Liddes, Voutaz and Rouyer 2013), (d) Late Iron Age (La Tène) vase from a grave (ca. 200-100 BC, Sembrancher, Curdy 2013), (e) Roman votive tablet (ca. AD 1-100, Col du Gd-St-Bernard, Wiblé 2008), (f) Adalbert I denarius from a grave (AD 1111-1137, Bourg-St-Pierre "L'Hospitalet", El Sherbini and Elsig 2001) 
alpine pastoralism and transhumance as documented around the Schnidejoch Pass (Hafner and Schwörer 2018).

Land use increased notably in the region after 3,900 cal BP (1950 cal BC) during the Early Bronze Age as indicated by the massive expansion of $A$. viridis, high fire activity and the continuous occurrence of human indicator and other herbaceous pollen ( $P$. lanceolata, Cerealia-type, Rumex acetosatype) in our record. Maximum concentrations of L. decidua macrofossils point to the establishment of larch-meadows similar to the Upper Engadine (Gobet et al. 2003). Functional hilltop settlements at mid altitudes are documented at several sites in the Valais (e.g. Zeneggen-Kastelltschuggen at 1,600 m a.s.1., David-Elbiali 1994; Curdy 2007) and high percentages of Cerealia-type (up to 4\%) at ZeneggenHellelen (Welten 1982b) unambiguously demonstrate that arable farming was practiced at $1,510 \mathrm{~m}$ a.s.l. Landolt et al. (2015) confirm that in general the upper continental montane zone is still well-suited for arable farming today but too dry for pastoral farming without irrigation. Former field terraces above Liddes $(1,400-1,600 \mathrm{~m}$ a.s.l.) indicate that crop cultivation was important at mid altitudes until the recent past (Benkert et al. 2010). Similarly, in the Upper Engadine, ancient field terraces occur as high as $1,800 \mathrm{~m}$ a.s.l. in the subalpine zone (Gobet et al. 2003). Taken together, it is very likely that cereals were cultivated at or close to our site in the Val d'Entremont. However, the archaeological evidence of a permanent settlement during the Bronze Age at Lac de Champex is currently lacking.

For the Iron Age/Roman Period (ca. 2,750-1,500 cal вр, 800 BC-AD 450), there is a slight increase of human activities visible in our record. In addition, regional archaeology shows the highest density of finds (Fig. 1), indicating that the valleys were important pathways for crossing the Alps and rather densely populated, which is supported by palaeoecological evidence from the lowlands (Tinner et al. 2003; Rey et al. 2020). In agreement, the rather remote site Lac de Fully (2,135 m a.sl., Finsinger and Tinner 2007) indicates the first substantial opening of the forests during this period and other subalpine sites point to an intensified land use (Tinner and Theurillat 2003). Pastoral farming was established with a widespread occurrence of seasonally occupied mayens and permanent villages at mid altitudes, as we know them today (Curdy 2007). This finding is supported by maximum influx values of Sporormiella spores in our record (Figs. 3, 4 and 7), suggesting that the area around Lac de Champex was probably used as an intermediate seasonal stop to reach the grazing grounds at higher elevation above the tree line.

The most intense land use activities are recorded for the last millennium at Lac de Champex. However, compared to other sites in the Alps at higher altitudes (Wick et al. 2003; Lotter et al. 2006; Schwörer et al. 2014; Thöle et al. 2016) and/or close to villages in the valley bottoms (Gobet et al.
2003; Curdy et al. 2009; Rey et al. 2013; Dietre et al. 2017), the forest openings remained less pronounced. The reason for such differences could be the less labour-intensive tree removal along the fairly open tree line ecotone at higher elevations and in the proximity of settlements compared to timber harvest in the rather closed forest at mid altitudes far away from villages. Alternatively, forests at intermediate altitudes were kept to protect the permanent settlements at lower altitudes from risks such as avalanches or debris flows, which are frequent in the Alps. Nevertheless, the construction of the artificial water channel from the neighbouring Arpette Valley (Lugon 1927) must have led to substantial changes in the lake ecosystems since a lot of fresh and oxygen-rich water was brought into the lake. From that time on, the lake was probably used as a natural freshwater reservoir to irrigate the meadows down in the valley around the village Orsières.

\section{Conclusions}

Our new palaeoecological record from Lac de Champex provides the first continuous and well-dated documentation of vegetation dynamics and land use from the upper continental montane zone of the Central Alps during the last 14,500 years. It suggests that first trees (Betula and $P$. sylvestris) were growing around the site at $1,500 \mathrm{~m}$ a.s.l. already during the Allerød (14,000 cal BP), which is in agreement with previous studies from the Central and Southern Alps. The tree line dropped below the site again during the Younger Dryas cooling (12,750-11,550 cal вP). Climate warming at the onset of the Holocene coincided with a rapid upward movement of the tree line between 11,500 and $11,200 \mathrm{cal} \mathrm{BP}$, leading to the establishment of mixed birchpine-larch forests at the lake. Favourable climatic conditions during the HTM probably even allowed for temperate tree species (i.e. Ulmus, Tilia and Acer) to grow at the elevation of our site. The expansion of mesophilous A. alba at 7,500 cal BP was likely caused by a climatic shift towards more oceanic conditions after the $8.2 \mathrm{ka}$ event. The co-existence of shade-tolerant $A$. alba and heliophilous $L$. decidua over millennia is unique since similar forests do not occur anywhere in the Alps nowadays. The replacement of mixed silver fir forests by mixed spruce forests after 5,000 cal bp was likely triggered by increasing farming activities in the region but occurred ca. 500 years later than in the Northern Alps. This delay may be explained by limited moisture availability in the Central Alps. Frequent fires linked to land use promoted the mass expansion of $A$. viridis shrublands after 4,000 cal BP. Compared to sites at the tree line and in the lowlands, the area around Lac de Champex was less affected by human exploitation of the landscape. Nevertheless, for millennia the mid altitudinal sites may have served 
as important linkages between the permanent settlements in the valleys and seasonally occupied mayens at higher elevations. Global warming will lead to unprecedented changes in the vegetation composition at mid altitudes in the Alps (Henne et al. 2011) thus temperate trees (Acer, Ulmus, Tilia and others) and deep-rooting, drought-tolerant A. alba may be able to re-establish, if browsing and fire do not become excessive, probably leading to more diverse forest ecosystems. However, warmer temperatures and drier summers may impede sustainable pastoral farming in the upper continental montane zone. More studies and a systematic reassessment of old palaeoecological records within the region (e.g. Zeneggen-Hellelen, Welten 1982b) are needed to better constrain the Holocene vegetational changes and the land use history at mid altitudes in this part of the Alps.

Supplementary Information The online version contains supplementary material available at https://doi.org/10.1007/s00334-021-00859-6.

Acknowledgements We are thankful to Willi Tanner, Carole Adolf and Moritz Gubler for their help during the fieldwork. This research was supported by the association "Recherches Archéologiques du Mur d'Hannibal" (RAMHA) and the village Liddes. We are grateful for the constructive comments of two anonymous reviewers on a previous version of the manuscript.

Author contributions FR, EG, RA and WT contributed to the conception and design of the study. Material preparation, data collections and analysis were performed by FR, SOB, RA, AB, HI, CM, NPGdM and JCR. A first version of the manuscript was written by FR, SOB, OH and CS. All authors commented on previous versions of the manuscript and approved the final version of this contribution.

Funding Open access funding provided by University of Basel.

Data availability All data is currently stored in the Alpine Pollen Database (ALPADABA) and will be made publicly available on Neotoma (https://www.neotomadb.org) upon publication of this article.

\section{Declarations}

Conflict of interest The authors have no conflict of interest to declare that are relevant to the content of this article.

Open Access This article is licensed under a Creative Commons Attribution 4.0 International License, which permits use, sharing, adaptation, distribution and reproduction in any medium or format, as long as you give appropriate credit to the original author(s) and the source, provide a link to the Creative Commons licence, and indicate if changes were made. The images or other third party material in this article are included in the article's Creative Commons licence, unless indicated otherwise in a credit line to the material. If material is not included in the article's Creative Commons licence and your intended use is not permitted by statutory regulation or exceeds the permitted use, you will need to obtain permission directly from the copyright holder. To view a copy of this licence, visit http://creativecommons.org/licenses/by/4.0/.

\section{References}

Ammann B, van Leeuwen JFN, van der Knaap WO et al (2013) Vegetation responses to rapid warming and to minor climatic fluctuations during the Late-Glacial Interstadial (GI-1) at Gerzensee (Switzerland). Palaeogeogr Palaeoclimatol Palaeoecol 391:40 59. https://doi.org/10.1016/j.palaeo.2012.07.010

Bahrenberg G, Giese E, Mevenkamp N, Nipper J (2008) Statistische Methoden in der Geographie, Band 2: Multivariate Statistik. Borntraeger, Stuttgart

Becker A, Ammann B, Anselmetti FS et al (2006) Paleoenvironmental studies on Lake Bergsee, Black Forest, Germany. N Jahrb Geol Paläont Abh 240:405-445

Benkert A, Curdy P, David-Elbiali M (2010) Sites de hauteur et contrôle du territoire aux âges des métaux dans la vallée du Rhône (Suisse / cantons du Valais et de Vaud). Bulletin D'études Préhistoriques Alpines 21:171-191

Bennett KD (1996) Determination of the number of zones in a biostratigraphical sequence. New Phytol 132:155-170. https://doi.org/10. 1111/j.1469-8137.1996.tb04521.x

Berthel N, Schwörer C, Tinner W (2012) Impact of Holocene climate changes on alpine and treeline vegetation at Sanetsch Pass, Bernese Alps, Switzerland. Rev Palaeobot Palynol 174:91-100. https://doi.org/10.1016/j.revpalbo.2011.12.007

Beug H-J (2004) Leitfaden der Pollenbestimmung für Mitteleuropa und angrenzende Gebiete. Pfeil, München

Birks HH (2001) Plant macrofossils. In: Smol JP, Birks HJB, Last WM (eds) Tracking Environmental Change Using Lake Sediments, vol 3. Terrestrial, Algal, and Siliceous indicators. Kluwer Academic Publishers, Dordrecht, pp 49-74

Birks HJB, Gordon AD (1985) Numerical methods in quaternary pollen analysis. Academic Press, London

Birks HJB, Line JM (1992) The use of rarefaction analysis for estimating palynological richness from quaternary pollen-analytical data. Holocene 2:1-10. https://doi.org/10.1177/0959683692 00200101

Blaauw M (2010) Methods and code for 'classical' age-modelling of radiocarbon sequences. Quat Geochronol 5:512-518. https://doi. org/10.1016/j.quageo.2010.01.002

Blarquez O, Carcaillet C, Bremond L et al (2010) Trees in the subalpine belt since $11700 \mathrm{cal}$. BP: origin, expansion and alteration of the modern forest. Holocene 20:139-146. https://doi.org/10. $1177 / 0959683609348857$

Bolland A, Rey F, Gobet E et al (2020) Summer temperature development 18000-14000 cal. BP recorded by a new chironomid record from Burgäschisee. Swiss Plateau. Quat Sci Rev 243:106484. https://doi.org/10.1016/j.quascirev.2020.106484

Burga CA (1980) Pollenanalytische Untersuchungen zur Vegetationsgeschichte des Schams und des San Bernardino-Passgebietes (Graubünden, Schweiz). Dissertationes Botanicae 56. Cramer, Vaduz

CH2011 (2011) Swiss Climate Change Scenarios CH2011. C2SM, MeteoSwiss, ETH, NCCR Climate, OCCC, Zurich

Colombaroli D, Tinner W (2013) Determining the long-term changes in biodiversity and provisioning services along a transect from Central Europe to the Mediterranean. Holocene 23:1,625-1,634. https://doi.org/10.1177/0959683613496290

Colombaroli D, Beckmann M, van der Knaap WO et al (2013) Changes in biodiversity and vegetation composition in the central Swiss Alps during the transition from pristine forest to first farming. Divers Distrib 19:157-170. https://doi.org/10.1111/j.1472-4642. 2012.00930.x

Curdy P (2007) Prehistoric settlement in middle and high altitudes in the Upper Rhone Valley (Valais-Vaud, Switzerland): a summary of twenty years of research. Preistoria Alpina 42:99-108 
Curdy P, Paccolat O, Wick L (2009) Les premiers vignerons du Valais. Archéol Suisse 32:2-19. https://doi.org/10.5169/seals-109982

Curdy P (2013) Vase "a trottola". In: Elsig P, Morand M-C (eds) Le Musée d'histoire du Valais, Sion. Collectionner au cœur des Alpes. Somogy Editions, Paris, pp 72-73

David-Elbiali M (1994) Les influences culturelles en Valais au début du Bronze final au travers des découvertes de ZeneggenKasteltschuggen. Annuaire De La Sociéte Suisse De Préhistoire Et Archéologie 77:35-52

Dietre B, Walser C, Kofler W et al (2017) Neolithic to Bronze Age (4850-3450 cal. BP) fire management of the Alpine Lower Engadine landscape (Switzerland) to establish pastures and cereal fields. Holocene 27:181-196. https://doi.org/10.1177/09596 83616658523

Dietre B, Reitmaier T, Walser C et al (2020) Steady transformation of primeval forest into subalpine pasture during the Late Neolithic to Early Bronze Age (2300-1700 BC) in the Silvretta Alps, Switzerland. Holocene 30:355-368. https://doi.org/10. 1177/0959683619887419

El Sherbiny C, Elsig P (2001) Le trésor monétaire de l'Hospitalet: risquer le passage du Grand-Saint-Bernard au XII ${ }^{\mathrm{e}}$ siècle. Vallesia 56:385-407

Finsinger W, Tinner W (2005) Minimum count sums for charcoal concentration estimates in pollen slides: accuracy and potential errors. Holocene 15:293-297. https://doi.org/10.1191/09596 $83605 \mathrm{hl} 1808 \mathrm{rr}$

Finsinger W, Tinner W (2007) Pollen and plant macrofossils at Lac de Fully (2135 m asl): Holocene forest dynamics on a highland plateau in the Valais, Switzerland. Holocene 17:1,119-1,127. https://doi.org/10.1177/0959683607082552

Finsinger W, Tinner W (2020) New insights on stomata analysis of European conifers 65 years after the pioneering study of Werner Trautmann (1953). Veget Hist Archaeobot 29:393-406. https://doi.org/10.1007/s00334-019-00754-1

Finsinger W, Vanel Q, Ribolini A, Tinner W (2021) Early to late Holocene vegetation and fire dynamics at the treeline in the Maritime Alps. Veget Hist Archaeobot 30:507-524. https:// doi.org/10.1007/s00334-020-00795-x

Gehrig-Fasel J, Guisan A, Zimmermann NE (2007) Tree line shifts in the Swiss Alps: Climate change or land abandonment? J Veg Sci 18:571-582. https://doi.org/10.1111/j.1654-1103. 2007.tb02571.x

Genries A, Mercier L, Lavoie M et al (2009) The effect of fire frequency on local cembra pine populations. Ecology 90:476-486. https://doi.org/10.1890/07-1740.1

Gobet E, Tinner W, Hochuli PA et al (2003) Middle to Late Holocene vegetation history of the Upper Engadine (Swiss Alps): the role of man and fire. Veget Hist Archaeobot 12:143-163. https://doi. org/10.1007/s00334-003-0017-4

Gobet E, Tinner W, Bigler C et al (2005) Early-Holocene afforestation processes in the lower subalpine belt of the Central Swiss Alps as inferred from macrofossil and pollen records. Holocene 15:672-686. https://doi.org/10.1191/0959683605hl843rp

Gobet E, Tinner W (2012) Von der Ur- zur Kulturlandschaft. In: Meyerhans A (ed) Geschichte des Kantons Schwyz 1: Zeiten und Räume, Frühzeit bis 1350. Chronos, Zürich, pp 37-57

Gobet E, van Leeuwen JFN, Tinner W (2017) Vegetationsdynamik, Landnutzung und Siedlungstätigkeit im Einzugsgebiet der Seeufersiedlungen im unteren Zürichseebecken. In: Bleicher N, Harb C (eds) Zürich-Parkhaus Opéra: Eine neolithische Feuchtbodenfundstelle. 3: Naturwissenschaftliche Analysen und Synthese. Monographien der Kantonsarchäologie Zürich 50, pp $11-30$

Haas JN, Richoz I, Tinner W, Wick L (1998) Synchronous Holocene climatic oscillations recorded on the Swiss Plateau and at timberline in the Alps. Holocene 8:301-309. https://doi.org/10. $1191 / 095968398675491173$

Hafner A, Schwörer C (2018) Vertical mobility around the high-alpine Schnidejoch Pass. Indications of Neolithic and Bronze Age pastoralism in the Swiss Alps from paleoecological and archaeological sources. Quat Int 484:3-18. https://doi.org/10.1016/j.quaint. 2016.12.049

Harsch MA, Hulme PE, McGlone MS, Duncan RP (2009) Are treelines advancing? A global meta-analysis of treeline response to climate warming. Ecol Lett 12:1,040-1,049. https://doi.org/10. 1111/j.1461-0248.2009.01355.x

Heegaard E, Birks HJB, Telford RJ (2005) Relationships between calibrated ages and depth in stratigraphical sequences: an estimation procedure by mixed-effect regression. Holocene 15:612-618. https://doi.org/10.1191/0959683605hl836rr

Heiri O, Wick L, van Leeuwen JFN et al (2003) Holocene tree immigration and the chironomid fauna of a small Swiss subalpine lake (Hinterburgsee, $1515 \mathrm{~m}$ a.s.l.). Palaeogeogr Palaeoclimatol Palaeoecol 189:35-53. https://doi.org/10.1016/S0031-0182(02) 00592-8

Heiri O, Koinig KA, Spötl C et al (2014) Palaeoclimate records 60-8 ka in the Austrian and Swiss Alps and their forelands. Quat Sci Rev 106:186-205. https://doi.org/10.1016/j.quascirev.2014.05. 021

Heiri O, Ilyashuk B, Millet L et al (2015) Stacking of discontinuous regional palaeoclimate records: Chironomid-based summer temperatures from the Alpine region. Holocene 25:137-149. https:// doi.org/10.1177/0959683614556382

Heiss AG, Kofler W, Oeggl K (2005) The Ulten Valley in South Tyrol, Italy: vegetation and settlement history of the area, and macrofossil record from the iron age cult site of St. Walburg. Palyno-Bulletin of the Institute of Botany, University of Innsbruck 1:63-73

Henne PD, Elkin CM, Reineking B et al (2011) Did soil development limit spruce (Picea abies) expansion in the Central Alps during the Holocene? Testing a palaeobotanical hypothesis with a dynamic landscape model. J Biogeogr 38:933-949. https://doi. org/10.1111/j.1365-2699.2010.02460.x

Hurlbert SH (1971) The nonconcept of species diversity: a critique and alternative parameters. Ecology 52:577-586. https://doi.org/10. $2307 / 1934145$

Ilyashuk BP, Gobet E, Heiri O et al (2009) Lateglacial environmental and climatic changes at the Maloja Pass, Central Swiss Alps, as recorded by chironomids and pollen. Quat Sci Rev 28:1,3401,353. https://doi.org/10.1016/j.quascirev.2009.01.007

IPCC (2014) Climate Change 2014: Impacts, Adaptation and Vulnerability. Part B: Regional Aspects. Contribution of Working Group II to the Fifth Assessment Report of the Intergovernmental Panel on Climate Change. Cambridge University Press, Cambridge and New York

Landolt E, Aeschimann D, Bäumler B, Rasolofo N (2015) Unsere Alpenflora: ein Pflanzenführer für Wanderer und Bergsteiger. SAC-Verlag, Bern

Lang G, Tobolski K (1985) Hobschensee - Late-Glacial and Holocene environment of a lake near the timberline. In: Lang G (ed) Swiss lake and mire environments during the last 15000 years. Dissertationes Botanicae. Cramer, Vaduz, pp 209-228

Lotter AF (1999) Late-glacial and Holocene vegetation history and dynamics as shown by pollen and plant macrofossil analyses in annually laminated sediments from Soppensee (Central Switzerland). Veget Hist Archaeobot 8:165-184. https://doi.org/10. 1007/BF02342718

Lotter AF, Heiri O, Hofmann W et al (2006) Holocene timberline dynamics at Bachalpsee, a lake at $2265 \mathrm{~m}$ a.s.l. in the northern Swiss Alps. Veget Hist Archaeobot 15:295-307. https://doi.org/ 10.1007/s00334-006-0060-z 
Lugon J (1927) Etude sur les bactéries du lac de Champex (1,465 m d'altitude) et sur leurs oscillations dans les différentes saisons. University of Lausanne, Lausanne

Magny M (2013) Orbital, ice-sheet, and possible solar forcing of Holocene lake-level fluctuations in west-central Europe: A comment on Bleicher. Holocene 23:1,202-1,212. https://doi.org/10.1177/ 0959683613483627

Magny M, Bossuet G, Ruffaldi P et al (2011) Orbital imprint on Holocene palaeohydrological variations in west-central Europe as reflected by lake-level changes at Cerin (Jura Mountains, eastern France). J Quat Sci 26:171-177. https://doi.org/10.1002/jqs.1436

MeteoSwiss, (2021) Klimadiagramme und Normwerte pro Station. Federal Office of Meteorology and Climatology MeteoSwiss, Zurich-Airport

Moore PD, Webb JA, Collinson ME (1991) Pollen analysis, 2nd edn. Blackwell, Oxford

Pini R (2002) A high-resolution Late-glacial - Holocene pollen diagram from Pian di Gembro (Central Alps, Northern Italy). Veget Hist Archaeobot 11:251-262. https://doi.org/10.1007/s0033 40200038

R Development Core Team (2020) R: a language and environment for statistical computing. R Foundation for Statistical Computing, Vienna

Rach O, Brauer A, Wilkes H, Sachse D (2014) Delayed hydrological response to Greenland cooling at the onset of the Younger Dryas in western Europe. Nat Geosci 7:109-112. https://doi.org/ 10.1038/ngeo2053

Reille M (1992) Pollen et spores d'Europe et d'Afrique du Nord. Laboratoire de Botanique Historique et Palynologie, Marseille

Reimer P, Austin W, Bard E et al (2020) The IntCal20 northern hemisphere radiocarbon age calibration curve $(0-55$ cal kBP). Radiocarbon 62:725-757. https://doi.org/10.1017/RDC.2020.41

Rey F, Schwörer C, Gobet E et al (2013) Climatic and human impacts on mountain vegetation at Lauenensee (Bernese Alps, Switzerland) during the last 14,000 years. Holocene 23:1,415-1,427. https://doi.org/10.1177/0959683613489585

Rey F, Gobet E, van Leeuwen JFN et al (2017) Vegetational and agricultural dynamics at Burgäschisee (Swiss Plateau) recorded for 18,700 years by multi-proxy evidence from partly varved sediments. Veget Hist Archaeobot 26:571-586. https://doi.org/10. 1007/s00334-017-0635-x

Rey F, Gobet E, Schwörer C et al (2019a) Causes and mechanisms of synchronous succession trajectories in primeval Central European mixed Fagus sylvatica forests. J Ecol 107:1,392-1,408. https://doi.org/10.1111/1365-2745.13121

Rey F, Gobet E, Szidat S et al (2019b) Radiocarbon wiggle matching on laminated sediments delivers high-precision chronologies. Radiocarbon 61:265-285. https://doi.org/10.1017/RDC.2018.47

Rey F, Gobet E, Schwörer C et al (2020) Climate impacts on vegetation and fire dynamics since the last deglaciation at Moossee (Switzerland). Clim Past 16:1347-1367. https://doi.org/10.5194/ cp-16-1347-2020

Schmid S, Fügenschuh B, Kissling E, Schuster R (2004) Tectonic map and overall architecture of the Alpine orogen. Eclogae Geol Helv 97:93-117. https://doi.org/10.1007/s00015-004-1113-x

Schoch W, Pawlik B, Schweingruber FH (1988) Botanische Makroreste: Ein Atlas zur Bestimmung häufig gefundener und ökologisch wichtiger Pflanzensamen. Haupt, Bern

Schwander J, Eicher U, Ammann B (2000) Oxygen isotopes of lake marl at Gerzensee and Leysin (Switzerland), covering the Younger Dryas and two minor oscillations, and their correlation to the GRIP ice core. Palaeogeogr Palaeoclimatol Palaeoecol 159:203-214. https://doi.org/10.1016/S0031-0182(00)00085-7

Schwörer C, Kaltenrieder P, Glur L et al (2014) Holocene climate, fire and vegetation dynamics at the treeline in the Northwestern
Swiss Alps. Veget Hist Archaeobot 23:479-496. https://doi.org/ 10.1007/s00334-013-0411-5

Schwörer C, Colombaroli D, Kaltenrieder P et al (2015) Early human impact (5000-3000 BC) affects mountain forest dynamics in the Alps. J Ecol 103:281-295. https://doi.org/10.1111/1365-2745. 12354

Šmilauer P, Lepš J (2014) Multivariate Analysis of Ecological Data using CANOCO 5. Cambridge University Press, Cambridge. https://doi.org/10.1017/CBO9781139627061

Stockmarr J (1971) Tablets with spores used in absolute pollen analysis. Pollen Spores 13:615-621

Stuiver M, Polach HA (1977) Discussion: reporting of ${ }^{14} \mathrm{C}$ data. Radiocarbon 19:355-363. https://doi.org/10.1017/S00338222000036 72

Szidat S, Salazar GA, Vogel E et al (2014) ${ }^{14} \mathrm{C}$ analysis and sample preparation at the new Bern Laboratory for the Analysis of Radiocarbon with AMS (LARA). Radiocarbon 56:561-566. https:// doi.org/10.2458/56.17457

Taramarcaz C, Curdy P (2013) Là-haut sur la montagne...: des îtres et des hommes: inventaire des ruines d'alpage dans le Val de Bagnes. Archéol Suisse 36:16-25

ter Braak CJF, Prentice IC (1988) A theory of gradient analysis. Adv Ecol Res 18:271-317. https://doi.org/10.1016/S0065-2504(03) 34003-6

Thöle L, Schwörer C, Colombaroli D et al (2016) Reconstruction of Holocene vegetation dynamics at Lac de Bretaye, a high-mountain lake in the Swiss Alps. Holocene 26:380-396. https://doi. org/10.1177/0959683615609746

Tinner W, Hu FS (2003) Size parameters, size-class distribution and area-number relationship of microscopic charcoal: relevance for fire reconstruction. Holocene 13:499-505. https://doi.org/10. 1191/0959683603hl615rp

Tinner W, Kaltenrieder P (2005) Rapid responses of high-mountain vegetation to early Holocene environmental changes in the Swiss Alps. J Ecol 93:936-947. https://doi.org/10.1111/j.1365-2745. 2005.01023.x

Tinner W, Lotter AF (2001) Central European vegetation response to abrupt climate change at $8.2 \mathrm{ka}$. Geology 29:551-554. https:// doi.org/10.1130/0091-7613(2001)029\%3c0551:CEVRTA\% 3e2.0.CO;2

Tinner W, Lotter AF (2006) Holocene expansions of Fagus silvatica and Abies alba in Central Europe: where are we after eight decades of debate? Quat Sci Rev 25:526-549. https://doi.org/10. 1016/j.quascirev.2005.03.017

Tinner W, Theurillat J-P (2003) Uppermost limit, extent, and fluctuations of the timberline and treeline ecocline in the Swiss Central Alps during the past 11,500 years. Arct Antarct Alp Res 35:158-169. https://doi.org/10.1657/1523-0430(2003)035[0158: ULEAFO]2.0.CO;2

Tinner W, Lotter AF, Ammann B et al (2003) Climatic change and contemporaneous land-use phases north and south of the Alps $2300 \mathrm{BC}$ to $800 \mathrm{AD}$. Quat Sci Rev 22:1,447-1,460. https://doi. org/10.1016/S0277-3791(03)00083-0

Tinner W, Colombaroli D, Heiri O et al (2013) The past ecology of Abies alba provides new perspectives on future responses of silver fir forests to global warming. Ecol Monogr 83:419-439. https://doi.org/10.1890/12-2231.1

Trautmann W (1953) Zur Unterscheidung fossiler Spaltöffnungen der mitteleuropäischen Coniferen. Flora Oder Allgemeine Botanische Zeitung 140:523-533. https://doi.org/10.1016/S03671615(17)31952-3

Trisos CH, Merow C, Pigot AL (2020) The projected timing of abrupt ecological disruption from climate change. Nature 580:496-501. https://doi.org/10.1038/s41586-020-2189-9

Valsecchi V, Tinner W (2010) Vegetation responses to climatic variability in the Swiss Southern Alps during the Misox event at the 
early-mid Holocene transition. J Quat Sci 25:1,248-1,258. https:// doi.org/10.1002/jqs. 1403

van Raden UJ, Colombaroli D, Gilli A et al (2013) High-resolution late-glacial chronology for the Gerzensee lake record (Switzerland): $\delta 180$ correlation between a Gerzensee-stack and NGRIP. Palaeogeogr Palaeoclimatol Palaeoecol 391:13-24. https://doi. org/10.1016/j.palaeo.2012.05.017

Vescovi E, Ravazzi C, Arpenti E et al (2007) Interactions between climate and vegetation during the Lateglacial period as recorded by lake and mire sediment archives in Northern Italy and Southern Switzerland. Quat Sci Rev 26:1,650-1,669. https://doi.org/10. 1016/j.quascirev.2007.03.005

Vescovi E, Tinner W, Beer R et al (2018) Vegetation history of the upper Leventina Valley from Neolithic to Roman times, recorded by pollen, spores, plant macrofossils, and charcoal. In: Della Casa P (ed) The Leventina prehistoric landscape (Alpine Ticino Valley, Switzerland). Zurich Studies in Archaeology 12. Chronos, Zürich, pp 207-225

Voutaz J-P, Rouyer P (2013) Découvrir le Grand-Saint-Bernard. Parole et Silence, Sion

Wehrli M, Tinner W, Ammann B (2007) 16,000 years of vegetation and settlement history from Egelsee (Menzingen, central Switzerland). Holocene 17:747-761. https://doi.org/10.1177/09596 83607080515

Welten M (1950a) Beobachtungen über den rezenten Pollenniederschlag in alpiner Vegetation. Bericht Über Das Geobotanische Forschungsinstitut Rübel in Zürich 1949:47-57

Welten M (1950b) Die Alpweidrodung im Pollendiagramm. Bericht Über Das Geobotanische Forschungsinstitut Rübel in Zürich 1949:57-67

Welten M (1944) Pollenanalytische, stratigraphische und geochronologische Untersuchungen aus dem Faulenseemoos bei Spiez. Veröffentlichungen des Geobotanisches Institut der ETH, Stifung Rübel, Zürich 21. Huber, Bern
Welten M (1952) Über die spät- und postglaziale Vegetationsgeschichte des Simmentals. Veröffentlichungen des Geobotanisches Institutes Rübel in Zürich 26. Huber, Bern

Welten M (1982a) Pollenanalytische Untersuchungen zur Vegetationsgeschichte des Schweizerischen Nationalparks. Ergebnisse der wissenschaftlichen Untersuchungen im Schweizerischen Nationalpark 16. Bündner Naturhistorisches und Nationalpark-Museum, Chur

Welten M (1982b) Vegetationsgeschichtliche Untersuchungen in den westlichen Schweizer Alpen: Bern-Wallis. Birkhäuser, Basel

Wermus E (1981) Sembrancher: habitat préhistorique alpin (VS). Département d'Anthropologie, Genève

Wiblé F (2008) Les tablettes votives. In: Appolonia L, Wiblé F, Framarin P (eds) Alpis Poenina, Grand-Saint-Bernard: Une voie à travers l'Europe, Séminaire de Clôture des 11/12 avril 2008 au Fort de Bard (Vallée d'Aoste). Projet Interreg III A Italie-Suisse 2000-2006, Aoste, pp 93-107

Wick L, Tinner W (1997) Vegetation changes and timberline fluctuations in the Central Alps as indicators of Holocene climatic oscillations. Arct Alp Res 29:445-458. https://doi.org/10.2307/ 1551992

Wick L, van Leeuwen JFN, van der Knaap WO, Lotter AF (2003) Holocene vegetation development in the catchment of Sägistalsee (1935 m asl), a small lake in the Swiss Alps. J Paleolimnol 30:261-272. https://doi.org/10.1023/A:1026088914129

Zoller H (1960) Pollenanalytische Untersuchungen zur Vegetationsgeschichte der insubrischen Schweiz. Denkschr Schweiz Nat. Forsch Ges 83:45-156

Publisher's Note Springer Nature remains neutral with regard to jurisdictional claims in published maps and institutional affiliations. 